\title{
Improving Health Care Management in Primary Care for Homeless People: A Literature Review
}

\author{
Maeva Jego ${ }^{1,2, *(1)}$, Julien Abcaya ${ }^{2}$, Diana-Elena Ștefan ${ }^{3}$, Céline Calvet-Montredon ${ }^{2}$ and \\ Stéphanie Gentile ${ }^{1}$ \\ 1 EA 3279 Research Unit-Public Health, Chronic Diseases and Quality of Life, Faculty of Medicine, \\ Aix-Marseille University, 27 Bd Jean Moulin, 13385 Marseille CEDEX 5, France; \\ StephanieMarie.GENTILE@ap-hm.fr \\ 2 Department of General Practice, Faculty of Medicine, Aix-Marseille University, 27 Bd Jean Moulin, \\ 13385 Marseille CEDEX 5, France; abcaya.julien@gmail.com (J.A.); celine.montredon@hotmail.fr (C.C.-M.) \\ 3 Faculty of Medicine, Carol Davila University of Medicine and Pharmacy, 37 Street Dionisie Lupu, Sector 1, \\ 030167 Bucharest, Romania; anaidpopescu@gmail.com \\ * Correspondence: Maeva.jego@univ-amu.fr; Tel.: +33-0491-324-240
}

Received: 9 December 2017; Accepted: 7 February 2018; Published: 10 February 2018

\begin{abstract}
Background: Homeless people have poorer health status than the general population. They need complex care management, because of associated medical troubles (somatic and psychiatric) and social difficulties. We aimed to describe the main characteristics of the primary care programs that take care of homeless people, and to identify which could be most relevant. Methods: We performed a literature review that included articles which described and evaluated primary care programs for homeless people. Results: Most of the programs presented a team-based approach, multidisciplinary and/or integrated care. They often proposed co-located services between somatic health services, mental health services and social support services. They also tried to answer to the specific needs of homeless people. Some characteristics of these programs were associated with significant positive outcomes: tailored primary care organizations, clinic orientation, multidisciplinary team-based models which included primary care physicians and clinic nurses, integration of social support, and engagement in the community's health. Conclusions: Primary health care programs that aimed at taking care of the homeless people should emphasize a multidisciplinary approach and should consider an integrated (mental, somatic and social) care model.
\end{abstract}

Keywords: homeless persons; primary health care; access to health care; health services accessibility

\section{Introduction}

Homelessness has increased during the past 30 years in high-income countries [1]. It is estimated that 4 million people experience homelessness each year in the European Union, and more than 2.5 million in the USA [1]. The European Typology on Homelessness and Housing Exclusion (ETHOS) offers a harmonized definition of homelessness. It considers four conditions: rooflessness (living rough or in emergency shelters), houselessness (people living in shelters, more long-term accommodations or due to being released from institutions), insecure housing, and inadequate housing (for example living in caravans on illegal campsites, living in unfit housing, or extreme overcrowding) [2]. In this definition homelessness reflects precariousness as a dynamic process where the accumulation of health and/or social factors of vulnerability lead at the end to social exclusion. In France, the Foundation Abbé Pierre's 2017 annual report estimated that about 900,000 persons lacked personal housing (living rough, in shelters, in hostels, with their family or their friends, or in inadequate/non-conventional accommodations), and about 4 million were homeless or experienced hard housing conditions [3]. More and more youth, women and families are affected by homelessness in Europe [1,4]. The homeless 
population is also ageing with a median age of 50 years in the USA [1]. Homeless people need complex health care, including medical (somatic and mental health care), psychological, and social support. Indeed, they have worse physical and mental health status and suffer from higher mortality than housed people $[1,5,6]$. Their poor health status is marked by chronic conditions, mental health problems, and substance use problems [7-9]. Prevalence rates for mental disorders go from $30 \%$ to more than $60 \%$, and more than $50 \%$ of homeless people have concurrent substance addiction and mental disorders [9-11]. However, they face multiple difficulties in accessing primary health care and receive less preventive health care than the general population $[12,13]$. The encountered barriers can be: the lack of proof of health insurance, difficulties in keeping appointments, a bad experience of care and the fear of discrimination, or competing priorities, such as food and shelter needs $[12,14,15]$. Homeless people are less likely to have a family doctor, compared to the housed population [16]. Their odds of having a family doctor decrease with time passed on the street [14]. A study led in Marseille (France) showed that when homeless people fell ill, the general practitioner is only the fifth solution to turn to (after doing nothing or going to emergency) [17]. Their health care pathways are marked by high rates of acute health care use (emergency department visits), and inpatient admission to hospital [12]. These barriers of access to health care and the inadequate pathways are seen across many countries, with or without universal health care insurance [18-21]. As a result, homeless people often face acute complications or consult when their health status is already deteriorated.

According to the World Health Organization, primary health care is "essential care based on practical, scientifically sound and socially acceptable methods and technology made universally accessible to individuals and families in the community ( . . . It is the first level of contact of individuals, the family, and the community with the national health system" [22]. Several studies showed that the integration of primary care in the management of homeless people improved the diagnosis and the treatment of chronic diseases, improved the care experience for homeless people, and reduced the emergency and inpatient hospital admissions [23,24]. However, it is necessary to deepen the knowledge about programs in primary care which could be useful for homeless people. Some high-quality literature reviews already evaluated interventions to improve health or access to health care for homeless people [12,25-30]. The interventions presented in these reviews were various and only a few of them described or evaluated primary care organizations or interventions. The lack of high-quality studies led by programs in primary care for homeless people explained why these systematic reviews, which included only moderate and high-quality articles, contain only a few studies that focus on this topic.

In this review we aimed to describe the main characteristics of primary care programs (organizations or interventions) that take care of homeless people, and to identify which could be most relevant for taking care of the homeless people.

\section{Materials and Methods}

We performed a literature review to identify articles that described and evaluated primary care programs for homeless people.

\subsection{Data Sources and Research Strategy}

We searched into the MEDLINE, PsycINFO, COCHRANE library, and Cairn.info databases primary articles published between 1 January 2012 and 15 December 2016. The research keywords were:

(("homeless") AND ("primary health care" OR "health services accessibility" OR "general practice" OR "general practitioner" OR "primary care" OR "family physician" OR "family doctor")) on MEDLINE, PsycINFO, and COCHRANE.

"Homeless AND primary health care", "homeless AND general practice", "homeless AND primary care", "homeless AND family physician", "homeless AND health services accessibility", "homeless AND general practitioner", "homeless AND family doctor" or the same terms in French, on cairn.info. 
We also performed a grey literature search, and we added relative articles as we read the references of the selected articles.

\subsection{Selection Criteria}

We selected primary articles which described and evaluated interventions or organizations in primary care, for youth and/or adult homeless people, in English or French. We did not include the review articles, considered as secondary research articles, but we used the references of these reviews to search other pertinent articles.

\subsection{Screening}

Two reviewers (Jego Maeva and Abcaya Julien) independently screened titles and abstracts, then full texts if the articles were firstly selected. Articles were firstly selected based on title and/or abstract if they were related to homeless people and seemed to describe and evaluate organizations or interventions in primary care for homeless people. A second wave of screening consisted of obtaining full-text articles and reading them from end to end to determine eligibility. Articles were then selected if they provided a sufficient description and evaluated these organizations or interventions. All the disagreements between the 2 reviewers were discussed at each step of the selection. Due to the lack of high-quality articles and comparative methodologies for evaluation, we voluntarily included all articles even if they were not comparative studies or gave few arguments for evaluation (which could be qualitative data, quantitative data, with or without strict comparative schemes).

\subsection{Level of Evidence}

We chose to include all relevant articles, regardless of their quality assessment, in an exploratory approach. The evidence level of each study included in this review was appraised on the U.S. Preventive Services Task Force (USPSTF) 2008. USPSTF has developed a guide to evaluate studies on clinical preventive services and health promotion, and provide recommendations on these themes [31,32]. The USPSTF uses the following hierarchy of research design:

- I (properly powered and conducted randomized clinical trials/well-conducted systematic review/meta-analysis),

- II-1 (well-designed controlled trial without randomization), II-2 (well-designed cohort or case-control analysis study),

- II-3 (multiple time-series, uncontrolled studies),

- III (opinions, based on clinical experience, descriptive studies or case reports, reports of expert committees).

The USPSTF grades the internal validity of randomized clinical trials, cohort studies, and case control studies on 3-point scales (good, fair and poor), which varies between study designs [33].

\subsection{Data Extraction and Evaluation}

We collected data about the general characteristics of studies (year, country where the study was performed, the kind of primary care concerned, and the kind of homelessness concerned), the method of studies, the description of the primary care programs, the outcomes for evaluation, and relative results. We separated the primary care programs between organizations (describing primary care structures, or models, taking care for homeless people) and interventions (specific interventions for homeless people led on primary care teams or with primary care providers). We described the main characteristics of the interventions and organizations presented in the selected articles. Then we classified these characteristics in main categories, as a descriptive thematic analysis. Secondarily, we synthetized the main results about the evaluation of each intervention or organization. We classified these results as follows: 
- Positive or negative effects (when comparisons were performed and statistical tests were available),

- Seem to be positive or negative (when studies used a qualitative method, or descriptive data for evaluation, or a comparison without statistical test was available).

\section{Results}

\subsection{Selection Process and Baseline Characteristics of Eligible Studies}

The literature search identified 704 articles, and 2 more articles were added with complementary research. After selection process, this literature review included 19 articles [34-52] (Figure 1).

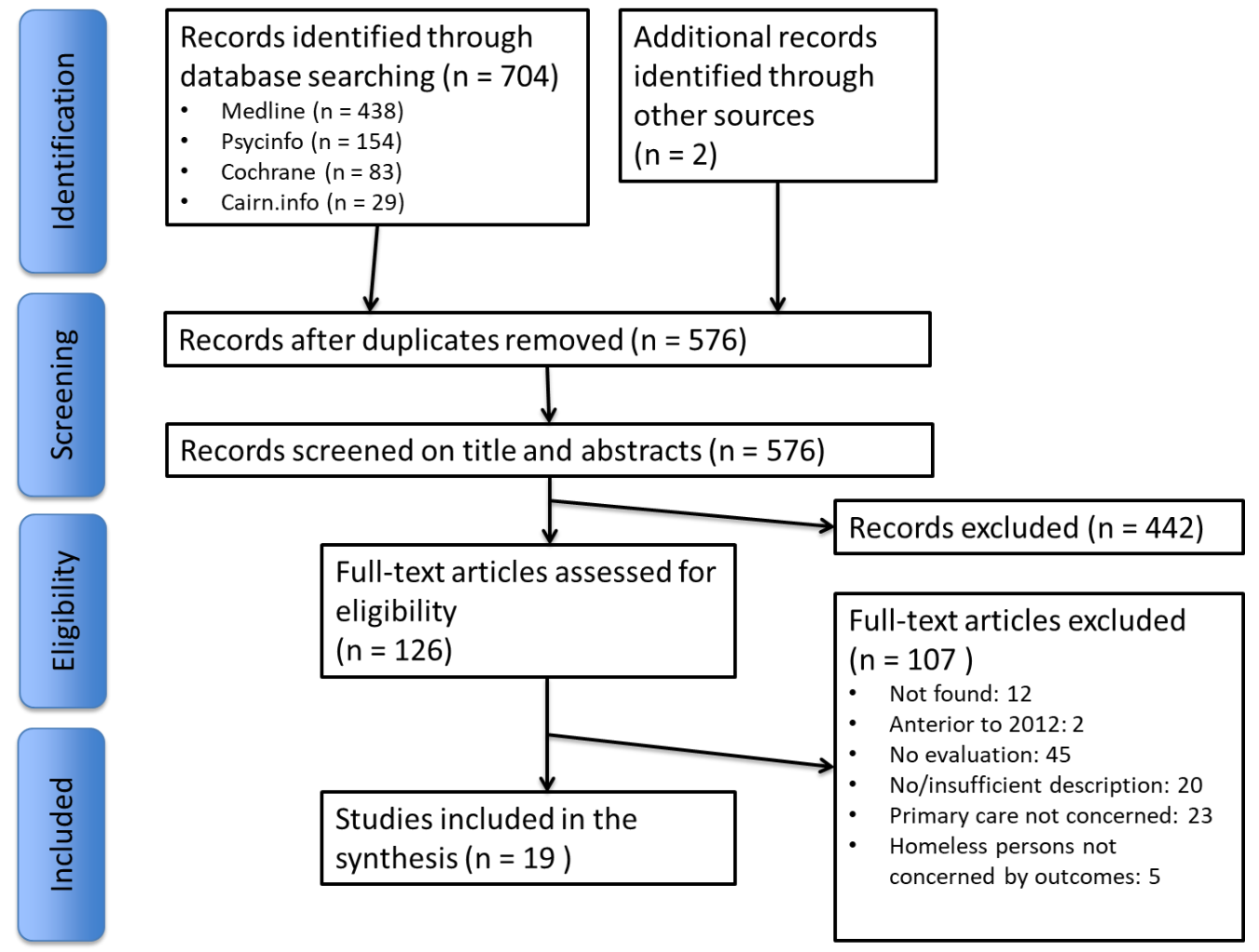

Figure 1. Flow diagram.

Most of the selected articles described and evaluated programs led in the USA (12), Canada (3) or the United Kingdom (2). The sample size ranged from 45 to 3543 patients. The level of evidence according to the U.S. Preventive Services Task Force (USPSTF) 2008 classification was various, going from I (higher level, with 2 randomized controlled trials) to III (lower level, concerning 6 studies, with qualitative studies, or low-quality material for evaluation). The internal validity of the studies was mostly fair and poor. Studies included youth, adult and veterans homeless with or without mental illness or substance abuse. Most of the homeless people lived in the street or in emergency or temporary sheltered accommodations. Primary care providers were mostly general practitioners, or nurses. The other primary care providers considered on the studies were non-specified paramedical providers, dentists and medical students. The target areas of the projects raised the following subjects: connected health, access, continuity and quality of care (care pathway), perception of health care by homeless and provider, social issues (with housing status) and training of medical students (Table 1). 
Table 1. General characteristics of included studies.

\begin{tabular}{|c|c|c|c|c|c|}
\hline Reference & Country & Study Type & $\begin{array}{l}\text { Effectives and Population (ETHOS }{ }^{1} \text { Categories } \\
\text { of Homelessness) }\end{array}$ & Target Areas & $\begin{array}{l}\text { Level of } \\
\text { Evidence/Validity }{ }^{2}\end{array}$ \\
\hline Dang et al., 2012 [51] & USA & Qualitative study & $\begin{array}{l}\text { Effectives: } 149 \\
\text { Homeless youth (ETHOS non-specified) }\end{array}$ & Connected health & $\mathrm{III}\left(\mathrm{NC}^{3}\right)$ \\
\hline Uddin et al., 2012 [40] & Bangladesh & $\begin{array}{l}\text { Comparative survey } \\
\text { (before/after) }\end{array}$ & $\begin{array}{l}\text { Effective: } 804 \\
\text { Homeless people (living rough) }\end{array}$ & $\begin{array}{l}\text { Access to health care/health } \\
\text { status/experience of care }\end{array}$ & II-3 (fair) \\
\hline Simons et al., 2012 [39] & UK & $\begin{array}{l}\text { Comparative survey } \\
\text { (Here and elsewhere) }\end{array}$ & $\begin{array}{l}\text { Effectives: } 350 \text { ( } 150 / 250 \text { for } 2 \text { clinics) } \\
\text { Homeless people (living rough, in accommodations for the } \\
\text { homeless, temporary or non-conventional structures) + } \\
\text { rehoused homeless people }\end{array}$ & $\begin{array}{l}\text { Access to health care/Continuity of } \\
\text { care/Health needs meet }\end{array}$ & II-3 (poor) \\
\hline Held et al., 2012 [52] & USA & $\begin{array}{l}\text { Comparative survey } \\
\text { (before/after) }\end{array}$ & $\begin{array}{l}\text { Effectives: } 150 \\
\text { People due to be released from institutions (jail) }\end{array}$ & $\begin{array}{l}\text { Social outcomes/access to health } \\
\text { care/Community integration }\end{array}$ & II-2 (fair) \\
\hline Omori et al., 2012 [43] & USA & Qualitative study & $\begin{array}{l}\text { Effectives: unknown } \\
\text { Homeless youth/families/adult (living in accommodation for } \\
\text { the homeless) }\end{array}$ & Experience of care/medical training & III (NC) \\
\hline Weinstein et al., 2013 [47] & USA & Mixed study & $\begin{array}{l}\text { Effectives: } 183 \text { (quantitative)/ } 11 \text { (qualitative) } \\
\text { Homeless people with mental illness (living rough, in a } \\
\text { night shelter) }\end{array}$ & $\begin{array}{l}\text { Quality of care/Public health missions } \\
\text { accomplishment }\end{array}$ & III (NC) \\
\hline Rowan et al., 2013 [34] & Canada & Mixed study & $\begin{array}{l}\text { Effectives: } 72 \text { (quantitative) } / 13 \text { (qualitative) } \\
\text { Homeless youth (living rough, in a night shelter, in insecure } \\
\text { accommodation, in temporary or non-standard structures, } \\
\text { unfit housing) }\end{array}$ & $\begin{array}{l}\text { Experience of care/Continuity of care } \\
\text { Program assessment }\end{array}$ & III (NC) \\
\hline Kertesz et al., 2013 [44] & USA & $\begin{array}{l}\text { Comparative survey } \\
\text { ( } 5 \text { centres) }\end{array}$ & $\begin{array}{l}\text { Effectives: } 601 \\
\text { Homeless people, veterans and not veterans (living rough, in a } \\
\text { night shelter, in temporary or non-standard structures) }\end{array}$ & Experience of care & II-2 (good) \\
\hline Patel et al., 2013 [37] & USA & $\begin{array}{l}\text { Comparative survey } \\
\text { (before/after) }\end{array}$ & $\begin{array}{l}\text { Effectives: } 47 \\
\text { Homeless veterans (ETHOS non-specified) }\end{array}$ & $\begin{array}{l}\text { Access and continuity of care/care } \\
\text { pathway/Housing }\end{array}$ & II-3 (poor) \\
\hline O'Toole et al., 2013 [38] & USA & $\begin{array}{l}\text { Case—control study }+ \\
\text { cohort analysis }\end{array}$ & $\begin{array}{l}\text { Effectives: } 233 \text { ( } 127 \text { cases } / 106 \text { controls) } \\
\text { Homeless veterans (living rough, in emergency } \\
\text { accommodations, in accommodations for the homeless, } \\
\text { temporally with families or friends) }\end{array}$ & Access to health care/screening & II-2 (fair) \\
\hline Campbell et al., 2013 [42] & Canada & Qualitative study & $\begin{array}{l}\text { Effectives: } 45 \\
\text { Homeless people (in accommodation for the homeless) }\end{array}$ & Experience of care/Access to health care & III (NC) \\
\hline Carson et al., 2013 [46] & USA & Retrospective study & $\begin{array}{l}\text { Effectives: } 123 \\
\text { Chronic homelessness and serious mental illness (ETHOS } \\
\text { non-specified) }\end{array}$ & Quality of care & III (poor) \\
\hline Lamb et al., 2014 [50] & UK & $\begin{array}{l}\text { Case study/literature } \\
\text { synthesis }\end{array}$ & $\begin{array}{l}\text { Effectives: } 86 \\
\text { Homeless people (living rough, in night shelter, in temporary } \\
\text { or non-standard structures) }\end{array}$ & Access to health care/Housing & III (NC) \\
\hline
\end{tabular}


Table 1. Cont.

\begin{tabular}{|c|c|c|c|c|c|}
\hline Reference & Country & Study Type & $\begin{array}{l}\text { Effectives and Population (ETHOS }{ }^{1} \text { Categories } \\
\text { of Homelessness) }\end{array}$ & Target Areas & $\begin{array}{l}\text { Level of } \\
\text { Evidence/Validity }\end{array}$ \\
\hline Chrystal et al., 2015 [45] & USA & $\begin{array}{l}\text { Comparative survey } \\
\text { ( } 5 \text { centers) }\end{array}$ & $\begin{array}{l}\text { Effectives: } 366 \\
\text { Homeless people with mental illness, veterans and } \\
\text { non-veterans (ETHOS non-specified) }\end{array}$ & Experience of care & II-2 (fair) \\
\hline O’Toole et al., 2015 [35] & USA & $\begin{array}{l}\text { Randomized controlled } \\
\text { trial }\end{array}$ & $\begin{array}{l}\text { Effectives: } 185(39,44,62,40 \text { for } 4 \text { arms) } \\
\text { Homeless veterans (living rough, night shelter, } \\
\text { in accommodation for the homeless, or transitional housing) }\end{array}$ & Access to health care & I (good) \\
\hline Stergiopoulos et al., 2015 [41] & Canada & Quasi-experimental study & $\begin{array}{l}\text { Effectives: } 140 \text { ( } 70 \text { in both arms) } \\
\text { Homeless with mental illness (living in shelter) }\end{array}$ & $\begin{array}{l}\text { Housing/Social outcomes/Access to } \\
\text { health care/quality of care }\end{array}$ & II-2 (fair) \\
\hline Upshur et al., 2015 [48] & USA & $\begin{array}{l}\text { Randomized controlled } \\
\text { trial }\end{array}$ & $\begin{array}{l}\text { Effectives: } 82 \\
\text { Homeless women with drinking problems (ETHOS } \\
\text { non-specified) }\end{array}$ & $\begin{array}{l}\text { Alcohol abuse/Continuity of care/health } \\
\text { status/housing status }\end{array}$ & $\mathrm{I}($ poor $)$ \\
\hline Hewett et al., 2016 [49] & UK & $\begin{array}{l}\text { Randomized controlled } \\
\text { trial }\end{array}$ & $\begin{array}{l}\text { Effectives: } 410 \text { ( } 206 / 204 \text { for } 2 \mathrm{arms} \text { ) } \\
\text { Homeless people (living rough, in emergency accommodation, } \\
\text { due to be released from institutions/living in temporary or } \\
\text { non-conventional structures) }\end{array}$ & $\begin{array}{l}\text { Care pathway/accommodations at } \\
\text { discharge/quality of life }\end{array}$ & I (good) \\
\hline O’Toole et al., 2016 [36] & USA & $\begin{array}{l}\text { Comparative survey } \\
\text { (before/after) }\end{array}$ & $\begin{array}{l}\text { Effectives: } 3543 \\
\text { Homeless veterans (ETHOS non-specified) }\end{array}$ & Access to Health care/care pathway & II-2 (fair) \\
\hline
\end{tabular}

${ }^{1}$ European Typology on Homelessness and Housing Exclusion [2]; ${ }^{2}$ According to the U.S. Preventive Services Task Force USPSTF 2008 classification (internal validity criteria are available for Randomized clinical trials, cohort studies and case-control studies); ${ }^{3} \mathrm{NC}$ : not concerned. 


\subsection{Components of Primary Care Programs for Homeless People}

Programs (organizations and interventions) in primary care for homeless people often included various components among organizational aspects, models and actions for health care, strategies for enhancing access and/or continuity of care, and non-medical actions. These programs involved mostly team-based, multidisciplinary and/or integrated care. Paramedical primary care providers (nurse managers or public health nurses) were often involved in the multidisciplinary teams. The primary health care models were dominated by patient-centered approach, community health, and care management. The programs often associated case management and patient support, social management, and proposed on-site basic needs. Many programs proposed co-located services between primary health care services, mental health care services, social support, and/or other services, in various combinations. Outreach strategies and low-threshold access were the most used strategies to enhance access to health care. Some programs used an electronic health record to enhance continuity of health care (Table 2).

\subsection{Effectiveness of Primary Care Organizations for Homeless People}

We isolated 13 articles which evaluated primary care organizations for homeless people [34,35,37-47] (Table 3). Most of the articles (9) evaluated tailored organizations for homeless people (pluriprofessional clinics, paramedical clinics and shelter-based clinics). Two studies compared pluridisciplinary clinics with different levels of tailoring (from mainstream to tailored care). Two other studies evaluated non-tailored primary care organizations (integrated primary care of patient-centered medical homes) collaborating with a tailored program for homeless people (housing first program). The organizations had mostly positive outcomes, especially on experience and satisfaction of care by homeless, staff and students, social and housing status, access to and use of health care services. Positive effects on experience and satisfaction of care have been described when: the structures were most tailored [43-45], had a friendly atmosphere [34], and offered on-site basic needs [34]. Many studies highlighted favorable outcomes on access to and use of health care [37-42], with an increasing of health care visits, and a better use of health care services (mental, primary health care, and others). For example, in a homeless primary-care-based medical home and in patient-aligned care teams, the number of homeless patient visits increased from 20 (before inclusion) to 185 (after inclusion) for the 47 patients included [37]. However, in one study that evaluated a partnership between a non-tailored patient-centered medical home and a housing first program, the on-site primary care physician was the personal physician for only 70 clients among the 183 housed clients and 50\% did not have a known primary care provider [47]. In this study, the primary-care provider from a non-tailored medical home performed on-site visits, on-demand from rehoused patients, and homeless people could choose their primary care provider to be another general practitioner. O'Toole et al. analyzed several Homeless "patient-aligned care teams" [35]. These homeless "patient-aligned care teams" consist of a primary care-based, interdisciplinary team model constructed on the principles of patient centeredness, a team-based, whole-person orientation to longitudinal care, and active communication and coordination among providers. The high-performing sites were significantly more likely to track housing status in the clinic notes, to have more than $50 \%$ full-time equivalent staffing of a clinic nurse, to have a primary care provider, to offer social services and supports embedded in the clinic, to offer food assistance or clothes on site, and to participate in community events or provide community outreach.

The impact on care pathways highlighted mostly a reduction of emergency department visits and hospitalizations for some studies [35,36,38], but persistent higher rates of emergency department use for homeless persons compared to persons who have a home were found [38].

The main limits concerned the accessibility of services, a limited capacity to enhance continuity of care, expressed difficulties for the staff to develop multidisciplinary collaboration, and to use electronic health records.

A detailed description of organizations in primary care and their components is available in Supplementary Material (Table S1). 
Table 2. Main components of primary care programs (organizations or interventions) for homeless people.

\begin{tabular}{|c|c|c|}
\hline Components of Programs (Refs.) & $\mathrm{Nb}(\%)$ & Details \\
\hline \multicolumn{3}{|l|}{ Organizational themes } \\
\hline Multidisciplinary care $[34-39,41,46,47,51,52]$ & $11(56 \%)$ & \\
\hline Team-based approach $[35,37-39,41,44-47]$ & $9(47 \%)$ & \\
\hline Active collaboration among providers $[35,37,48]$ & $3(16 \%)$ & Coordination, communication between providers, collaborative care \\
\hline Integrated care/services $[34,36,39,41,43,45-47,50,52]$ & $10(53 \%)$ & $\begin{array}{l}\text { Primary care and mental health care; Health care and social care } \pm \text { housing support; } \\
\text { whole integration (primary care, mental health care, social and housing support) }\end{array}$ \\
\hline Paramedical primary care $[36-38,40,46,49-51]$ & $8(42 \%)$ & $\begin{array}{l}\text { Nurses: Case manager, research nurses, public health nurses/others (dental, other } \\
\text { paramedics non-specified) }\end{array}$ \\
\hline Staff training $[35,44,45,48]$ & $4(21 \%)$ & Homeless-focused training, primary care providers training for interventions \\
\hline Co-located services $[34,35,38,39,44,46,52]$ & $7(37 \%)$ & $\begin{array}{l}\text { Various combinations with Primary-care; Mental health; Drop-in center; Health care } \\
\text { and social } \pm \text { housing; other: paramedical, family planning, dental ... }\end{array}$ \\
\hline Multi agencies or interprofessional partnerships $[34,44,47,49,51]$ & $5(26 \%)$ & $\begin{array}{l}\text { Shelters, homeless organizations, medical center, housing first program, public } \\
\text { health center, academic center, multi-agencies care plans }\end{array}$ \\
\hline Primary care centres linkage [41] & $1(5 \%)$ & \\
\hline Training missions $[34,41-43]$ & $4(21 \%)$ & $\begin{array}{l}\text { Teaching clinic, linkage with teaching hospital, medical students, dental students, } \\
\text { academic linkage }\end{array}$ \\
\hline Public health concerns $[47,51]$ & $2(11 \%)$ & \\
\hline Shelter-based care $[41,43,46]$ & $3(16 \%)$ & \\
\hline Hospital in-reach team [49] & $1(5 \%)$ & \\
\hline \multicolumn{3}{|l|}{ Models and actions for health care } \\
\hline Community health $[35,39,41,49,52]$ & $5(26 \%)$ & $\begin{array}{l}\text { Collaboration with community agencies, integration with community } \\
\text { services, linkage }\end{array}$ \\
\hline Preventive care and screening $[40,43]$ & $2(11 \%)$ & \\
\hline Care management $[35,36,38,40,43,46,48]$ & $7(37 \%)$ & $\begin{array}{l}\text { Coordination of care, addressing, intensive care management, linkage to primary or } \\
\text { specialized care }\end{array}$ \\
\hline Coordinated care $[37-43,46,48]$ & $9(47 \%)$ & \\
\hline Comprehensive care $[37,52]$ & $2(10 \%)$ & \\
\hline
\end{tabular}


Table 2. Cont.

\begin{tabular}{|c|c|c|}
\hline Components of Programs (Refs.) & $\mathrm{Nb}(\%)$ & Details \\
\hline Patient-centered approach $[35,36,39,47,48,50]$ & $6(32 \%)$ & $\begin{array}{l}\text { Patient-centered care, Health assessment, goal setting, whole patient orientation, } \\
\text { holistic care, case-based approach, self-management support }\end{array}$ \\
\hline Health education for users $[36,39,40,43,47]$ & $5(26 \%)$ & \\
\hline Brief intervention $[36,48]$ & $2(11 \%)$ & \\
\hline \multicolumn{3}{|l|}{ Tools for enhanced continuity of care } \\
\hline Personal card (paper) [40] & $1(5 \%)$ & \\
\hline Electronic health record $[38,41,48,51,52]$ & $5(26 \%)$ & Shared or not \\
\hline Monitoring systems [46] & $1(5 \%)$ & \\
\hline \multicolumn{3}{|l|}{ Other non-medical actions } \\
\hline Case management/patient support $[36,37,41,49,50,52]$ & $6(32 \%)$ & including accompaniment \\
\hline On-site basic needs availability $[34-36,38,45]$ & $5(26 \%)$ & \\
\hline Social management $[35,36,38,42,43,46,50]$ & $7(37 \%)$ & Social support with social workers/social management by physician \\
\hline Well-being actions $[43,48]$ & $2(10 \%)$ & Fun events, gifts, wellness counseling \\
\hline Peer-workers $[44,45]$ & $2(10 \%)$ & \\
\hline \multicolumn{3}{|l|}{ Access to care awareness } \\
\hline Information of users $[36,39,40]$ & $3(16 \%)$ & \\
\hline Low threshold access $[35,38,39,42,43,45,52]$ & $7(37 \%)$ & $\begin{array}{l}\text { Free care, walk-in, with or without appointments, emergency appointments, open } \\
\text { access, on-demand }\end{array}$ \\
\hline Outreach $[35,39,40,43-45,47,50]$ & $8(42 \%)$ & Active outreach, mobility, outreach within community, street or shelters outreach \\
\hline Friendly atmosphere $[34,40]$ & $2(11 \%)$ & Decorations for local of vans \\
\hline
\end{tabular}


Table 3. Effectiveness of primary care organizations for homeless people.

\begin{tabular}{|c|c|c|}
\hline Primary Care Organizations & Ref. & Method for Evaluation and main Results \\
\hline \multicolumn{3}{|l|}{ 1/Tailored organizations } \\
\hline \multirow{4}{*}{$\begin{array}{l}\text { Medical and dental primary } \\
\text { care (pluriprofessional) }\end{array}$} & \multirow{4}{*}{ Rowan et al. [34] } & $\begin{array}{l}\text { Method: qualitative (interviews with providers, focus groups with youth) } \\
\text { Seem to be positive (qualitative data): }\end{array}$ \\
\hline & & $\begin{array}{l}\text { - } \quad \text { satisfaction by youth (atmosphere, location, free things provided, free care) and staff (perceived role, relation } \\
\text { with youth) }\end{array}$ \\
\hline & & Seem to be negative (qualitative data): \\
\hline & & $\begin{array}{ll}\text { - } & \text { Staff (difficulties for interdisciplinary collaboration and electronic medical record use) } \\
\text { - } & \text { Youth (limited accessibility of services) }\end{array}$ \\
\hline \multirow{7}{*}{$\begin{array}{l}\text { Homeless primary-care-based } \\
\text { medical homes and } \\
\text { patient-aligned care teams } \\
(\text { PCMH-PACT) }\end{array}$} & \multirow{3}{*}{ O’Toole et al. [35] } & $\begin{array}{l}\text { Method: compared pre- and post-enrollment (at } 6 \text { months) use of health services/stratified site (high/moderate/low } \\
\text { performing) then compared their parameters. } \\
\text { Seem to be positive (no statistical test): }\end{array}$ \\
\hline & & _ $\quad$ care pathway: at 6 months, $\downarrow$ Emergency Department visits from 19\%/Hospitalizations from $34.7 \%$ \\
\hline & & $\begin{array}{l}\text { Characteristic of high-performing sites: more likely to: track housing status } * \text {, have }>50 \% \text { full-time equivalent staffing of a } \\
\text { clinic nurse }{ }^{*} \text {, have primary care provider } * \text {, have social services and supports embedded in the clinic } * \text {, offer food assistance } \\
\text { on site }{ }^{*} \text {, have a clothes pantry } * \text {, participate in community events * or community outreach } *\end{array}$ \\
\hline & Patel et al. [37] & $\begin{array}{l}\text { Method: pre-post evaluation with univariate analyses } \\
\text { Positive: }\end{array}$ \\
\hline & \multirow{3}{*}{ O’Toole et al. [38] } & $\begin{array}{l}\text { Method: comparison between homeless and non-homeless patients (at baseline and at } 6 \text { months)/comparison for homeless } \\
\text { people subgroup with pre-post evaluation. } \\
\text { Positive: }\end{array}$ \\
\hline & & $\begin{array}{l}\text { - Use of health care (during first } 6 \text { months): mental health services ( } 88 \% \text { for H PACT versus } 43.4 \% \text { for non-homeless *) } \\
\text { substance abuse treatment services ( } 37.8 \% \text { for H PACT versus } 7.5 \% \text { for non-homeless *) } \\
\text { emergency department use (before/after): } \downarrow \text { for homeless veterans who accessed primary care at higher rates * or who } \\
\text { used specialty and primary care*. }\end{array}$ \\
\hline & & Negative: emergency department use higher during first 6 months for H PACT * \\
\hline
\end{tabular}


Table 3. Cont

\begin{tabular}{|c|c|c|}
\hline Primary Care Organizations & Ref. & Method for Evaluation and main Results \\
\hline \multirow{4}{*}{ Dental clinic } & \multirow{4}{*}{ Simons et al. [39] } & $\begin{array}{l}\text { Method: comparison between Mobile dental service (MDS) and dedicated dental service (DDS) (no test)/bivariate analyses } \\
\text { to assess the relationship between service use and the overall outcomes of care } \\
\text { Seem to be positive: }\end{array}$ \\
\hline & & $\begin{array}{l}\text { - Access: better for mobile clinic: more rough sleepers accessing the MDS mobile dental service }(10 \%) \text { compared to the } \\
\text { DDS (dedicated dental service) (1\%). } \\
\text { Efficiency improvement: lost clinical time } \downarrow \text { between } 2009 \text { and } 2011\end{array}$ \\
\hline & & Seem to be negative: \\
\hline & & $\begin{array}{l}\text { - Continuity of care: } 36.7 \% \text { patients lost after the first appointment (more from the MDS than the DDS). Only } 27.8 \% \\
\text { of patients completed a course of treatment. }\end{array}$ \\
\hline \multirow{5}{*}{ Paramedics-led clinic } & \multirow{5}{*}{ Uddin et al. [40] } & $\begin{array}{l}\text { Method: mixed-method approach combining both quantitative and qualitative techniques } \\
\text { Positive: }\end{array}$ \\
\hline & & - $\quad$ Morbidity: $\downarrow$ in both models for women and men street-dwellers * \\
\hline & & - $\quad$ Use of health care services: $\uparrow$ in both models for women and men street-dwellers * \\
\hline & & - $\quad$ Health behaviors/prevention: $\uparrow$ family-planning method use in both models* \\
\hline & & Seem to be positive: perception of street-dwellers and service providers \\
\hline \multirow[b]{2}{*}{$\begin{array}{l}\text { Shelter-based clinics } \\
\text { (collaborative care models) }\end{array}$} & \multirow[b]{2}{*}{ Stergiopoulos et al. [41] } & $\begin{array}{l}\text { Method: Multivariate regression models to compare study arms } \\
\text { Positive: }\end{array}$ \\
\hline & & $\begin{array}{l}\text { - Community functioning: scores at } 6 \text { months and } 12 \text { months higher than at baseline * for shifted outpatient } \\
\text { collaborative care model (SOCC) and integrated multidisciplinary collaborative care (IMCC). } \\
\text { - } \quad \text { Health services utilization: improved, with more effect for SOCC }[\downarrow \text { emergency department visits at } 6 \text { and } 12 \text { months } \\
\text { (Odd Ratio (OR) }=0.51 \text { IC } 95 \%(0.30-0.87) \text { and OR }=0.48 \text { IC } 95 \%(0.26-0.90)^{*} \text { respectively } / \downarrow \text { overnight hospital visits at } \\
6 \text { and } 12 \text { months (OR }=0.45 \text { IC } 95 \%(0.26-0.79) \text { and OR }=0.33 \text { IC } 95 \%(0.17-0.63)^{*} \text {, respectively) } \uparrow \uparrow \text { Community } \\
\left.\text { physician visit in the past } 30 \text { days at } 12 \text { months (OR }=2.07 \text { IC } 95 \%(1.14-3.74)^{*}\right]\end{array}$ \\
\hline $\begin{array}{l}\text { Shelter-based clinics } \\
\text { (Student-run clinic) }\end{array}$ & Campbell et al. [42] & $\begin{array}{l}\text { Method: qualitative (individual and group semi-structured interviews with stakeholders) } \\
\text { Seem to be positive: Education purpose/Better relationships perceived/Feeling that students were in a good position to } \\
\text { help make referrals to specialists' care (non-client participants)/Increased capacity to access (two more than the physician } \\
\text { would see when working without students)/co-location in shelter well perceived } \\
\text { Seem to be negative: Access (only for a subset of the homeless population/Limit for providing continuity of care)/Student } \\
\text { knowledge and experience as a limit }\end{array}$ \\
\hline
\end{tabular}


Table 3. Cont

\begin{tabular}{|c|c|c|}
\hline Primary Care Organizations & Ref. & Method for Evaluation and main Results \\
\hline & \multirow{2}{*}{ Omori et al. [43] } & $\begin{array}{l}\text { Method: descriptive and qualitative data (non-specified) } \\
\text { Seem to be positive: }\end{array}$ \\
\hline & & _ $\quad$ Patients' benefits: high satisfaction ratings. \\
\hline \multirow[t]{2}{*}{$\begin{array}{l}\text { Pluriprofessional primary } \\
\text { care clinics }\end{array}$} & Kertez et al. [44] & $\begin{array}{l}\text { Method: survey-based comparison } \\
\text { Positive for tailored sites: more positive experiences at the tailored non-Veterans Affairs (VA) site than at the } 3 \text { mainstream } \\
\text { VA sites. Adjusting for patient characteristics, differences remained significant for the relationship and } \\
\text { cooperation */Unfavorable experience } 1.5 \text { to } 2 \text { times more common at the mainstream VA sites compared with the tailored } \\
\text { non-VA site* }\end{array}$ \\
\hline & Chrystal et al. [45] & $\begin{array}{l}\text { Method: survey-based comparison } \\
\text { Positive for tailored sites: site of care with tailored sites and Mainstream A (the one with some tailoring) obtained more } \\
\text { favorable scores for experience of care (mean }=3.14 \text { in tailored non-VA/3.05 in tailored VA/3.06 in mainstream VA A/2.96 in } \\
\text { mainstream VA B/ } 2.93 \text { in mainstream VA C * }\end{array}$ \\
\hline \multicolumn{3}{|c|}{ 3/Non-tailored organizations collaborating with tailored structures } \\
\hline \multirow{2}{*}{$\begin{array}{l}\text { Integrated health care: Housing } \\
\text { first with integrated primary } \\
\text { health care }\end{array}$} & \multirow{2}{*}{ Weinstein et al. [46] } & $\begin{array}{l}\text { Method: retrospective data, comparison between housing first and integrated care subgroup (no test) } \\
\text { Seem to be positive: }\end{array}$ \\
\hline & & $\begin{array}{l}\text { Quality of care/screening: Receipt of Recommended Quality Assurance Measures (higher in integrated care subgroup } \\
\text { compared to Housing first participants, for every categories) }\end{array}$ \\
\hline $\begin{array}{l}\text { University patient-centered } \\
\text { medical home }\end{array}$ & Weinstein et al. [47] & $\begin{array}{l}\text { Method: auto-rating on Likert values } \\
\text { Seem to be positive (no comparison): partnership functioning as an integrated person-centered health home. Addressed } \\
\text { the public health objectives according to "10 Essential Public Health Services" } \\
\text { Seem to be negative (no comparison): The on-site primary care physician was the personal physician for } 70 \text { clients on the } \\
183 \text { housed clients; } 50 \% \text { did not have a known PCP }\end{array}$ \\
\hline
\end{tabular}




\subsection{Effectiveness of Primary Care Interventions for Homeless People}

We isolated 6 articles that evaluated primary care interventions for homeless people [36,48-52] (Table 4). The first study (Project Renewal) involved an alcohol treatment intervention based on a chronic care model. The project was based on a clinic whose primary care providers (physician assistant and nurse practitioner) deal with homeless people. This project showed some positive elements (initiation, retention, engagement in treatment and positive experience of participants). However, the results were not statistically significant for mental and physical health status and neither for housing and median number of drinks by month [48].

The second study (Pathway project) consisted of a nurse-led and general practice-led in-hospital intervention. This project underscored socio-economic benefits (housing, money, relationship) but had no statistical effect on readmissions, re-attendance at emergency department, duration of hospitalization, drug and alcohol use [49].

The third study (StreetMed) was based on a nurse-led primary health care team. The effects on access to health care, registration with general practitioner, continuity of care, housing, or substance abuse reduction seemed to be positive (but no statistical test was available) [50].

The fourth study evaluated outreach interventions that included personal health assessments and brief interventions, and a clinic/health system orientation separately and in combination. The authors tested whether these interventions would increase health-seeking behavior and receipt of health care, compared to usual care [36]. On the "personal health assessment and brief intervention" arm, a research nurse interviewed participants and then provided feedback and a brief intervention. On the "Clinic orientation" arm, participants were transported to the clinic by the research assistant where they were introduced to the clinic team. Depending on patient preference and team availability, they were shown where they would need to go to check in, what the process was for being seen, as well as additional resources available at the clinic or where ancillary services were located. On the "usual care" arm, homeless people received a social worker-administered assessment of homeless history and social needs, a description of homeless programs' services, and verbal and written descriptions of clinical services, with instructions on how they could access care, where to go, and what processes and procedures were involved. Only personal health assessment/brief intervention associating clinic orientation, and clinic orientation alone demonstrated significant improvement in access to primary health care at 1 and 6 months.

The fifth study (Health shack project) described an electronic health record model developed for homeless youth. This health record was youth-centered, youth-controlled, internet-based, and confidential. The implementation of this record involved a partnership between a drop-in community agency that provided direct services and shelter to homeless youth, the physicians within an academic medical center, and the software developer. This project was acceptable for the youth and seemed to improve the care behavior of the homeless youth. Some limits of the project were highlighted concerning the lack of continuity of care for the homeless youth and limits on reaching the youth [51].

The sixth study (Jail Inreach project) consisted of integrated health care with primary care providers who collaborate with mental health providers, social workers and case managers. This project highlighted social benefits (decreased incarceration, social follow-up post release), and medical benefits (continuity and access to health care) [52].

More detailed descriptions of interventions are available in supplementary material (Table S1). 
Table 4. Effectiveness of interventions in primary care for homeless people.

\begin{tabular}{ll}
\hline Interventions $\quad$ Ref. \\
\hline Interventions involving tailored primary care
\end{tabular}

Project renewal:

alcohol treatment
intervention based on Upshur et al. [48]

chronic care model

Upshur et al. [48]

Pathway project:

nurse-led and General

Practitioner-led

in-hospital

intervention

Hewett et al. [49]

Intervention from primary care

providers (nurse and general

practitioners in hospital

providers (Doctors of Medici care

physician assistants and

nurse practitioners)

\section{Method for Evaluation and Main Results}

ethod: randomized controlled trial, comparison between average number of drinks with linear regression

Positive: initiation, engagement and retention in treatment: $\frac{1}{4}$ of intervention women versus $>50 \%$ women who did not use this service at 3 months *; $76 \%$ group intervention versus $44 \%$ in usual care had three or more contacts with any substance use treatment *; $75 \%$ versus $47 \%$ at 6 months * Mean of 12.1 total visits (with case manager) versus 6.2 for usual care *

Seem to be positive: experience of participants: Most were positive about the intervention experience (qualitative data).

Method: randomized parallel-arm trial, adjusted regression model for comparison

Positive:

- Housing: $14.6 \%$ of patients in the control arm were street homeless at discharge compared with $3.8 \%$ of patients in the intervention arm (odds ratio $=0.14$ ) *

- Money: Intervention $\uparrow$ score for money (mean 3.85 at baseline versus 5.21 at follow-up) *

- $\quad$ Relationship: intervention $\uparrow$ score for relationships (mean 4.79 at baseline versus 5.68 at follow-up) *

Method: descriptive data about effectiveness outcomes + case study

Seem to be positive (no statistical test/case study):

Streamed: nurse-led Lamb et al. [50] Nurse-led team primary

- Access: The number of patients registered with a general practitioner increased from 17 to 48 (on 86 patients), and the percentage of rough sleepers or those without secure accommodation reduced from 68 to $37 \%$ (p unknown)

- Multiple positive consequences described but on a case study treating about 1 case (joe 54 years old) (access, continuity, substance abuse reduction, housing project ... .)

Method: randomized controlled trial, uni- and bivariate analyses for comparison (ANOVA, Cox proportional-hazards regression survival analysis)

Positive: access to primary care at 6 months improved only for $\mathrm{CO}$ (clinic orientation) and

PHA/BI (Personal Health assessment/Brief intervention) +CO (cox regression using usual care as reference):

$\begin{aligned} & \text { Outreach } \\ & \text { interventions }\end{aligned} \quad$ O'Toole et al. [36] Outreach interventions

- $\quad \mathrm{PHA} / \mathrm{BI}+\mathrm{CO} \rightarrow$ At 1 month, $77.3 \%$ accessed primary care versus $30.6 \%$ in usual care arm/At 6 months, $88.7 \%$ accessed primary care versus $37.1 \%$ for Usual care, hazard ratio $=3.41$ *

- CO-only: At 1 month, $50 \%$ versus $30.6 \%$ in usual care arm/ At 6 months, $80 \%$ versus $37.1 \%$ in usual care, hazard ratio $=2.64$ * 
Table 4. Cont

\begin{tabular}{|c|c|c|c|}
\hline Interventions & Ref. & Brief Description of Interventions & Method for Evaluation and Main Results \\
\hline \multicolumn{4}{|c|}{ Interventions involving non-tailored primary care but collaborating with tailored structure } \\
\hline \multirow{4}{*}{$\begin{array}{l}\text { Health shack: } \\
\text { web-based personal } \\
\text { health information } \\
\text { system }\end{array}$} & \multirow{4}{*}{ Dang et al. [51] } & \multirow{4}{*}{$\begin{array}{l}\text { Partnership with a tailored } \\
\text { structure drop-in community } \\
\text { agency for homeless, the software } \\
\text { developer, and physicians within } \\
\text { an academic medical center, } \\
\text { and the software developer. }\end{array}$} & $\begin{array}{l}\text { Method: descriptive data and mostly qualitative evaluation } \\
\text { Seem to be positive (qualitative data): }\end{array}$ \\
\hline & & & $\begin{array}{l}\text { - Acceptability for youth: youth felt positive about enrolling in Health shack and were } \\
\text { comfortable using this technology. They denied concerns about confidentiality after meeting } \\
\text { with the public health nurses and being informed about confidentiality laws. } \\
\text { - Care behavior: many Health shack participants voluntarily returned to see the public health } \\
\text { nurses to discuss confidential health issues. }\end{array}$ \\
\hline & & & Seem to be negative (qualitative data): \\
\hline & & & $\begin{array}{l}\text { - } \quad \text { Follow-up: loss of contact with some potential enrollees. } \\
\text { - } \quad \text { Reach: youth referred by Health Ambassadors sometimes did not show up as planned, } \\
\text { and attempts to reach youth were unsuccessful }\end{array}$ \\
\hline Jail Inreach Project & Held et al. [52] & $\begin{array}{l}\text { Integrated health care: primary } \\
\text { care providers collaborating with } \\
\text { mental health providers and social } \\
\text { workers/case managers }\end{array}$ & $\begin{array}{l}\text { Method: comparison with analyses of variance test (univariate) } \\
\text { Positive: Outcomes relative with incarceration (county Jail } \downarrow / \text { number of charges per person } \downarrow / \\
\text { total number of average felonies per year } \downarrow / \text { total average misdemeanors } \downarrow \text { )* } \\
\text { Seem to be positive (no test): Continuity of care/access: }>50 \% \text { of jail releases referred to the Jail } \\
\text { Inreach Project continued with services after returning to the community, VS }<33 \% \text { of releases not } \\
\text { participating in the program. } 65.7 \% \text { of the study sample who were approached by a case manager } \\
\text { while incarcerated and agreed to participate were linked to community health and social services } \\
\text { post release via the Jail Inreach Project. }\end{array}$ \\
\hline
\end{tabular}




\section{Discussion}

\subsection{Main Results}

Primary care programs for homeless people involved mostly team-based, multidisciplinary and/or integrated care. Many programs proposed co-located services between primary health care services, mental health care services, social support, or other services, in various combinations. Most of the programs had strategies to enhance access to health care, dominated by outreach strategies and low threshold access. The primary health care models were dominated by patient-centered approach, community health, comprehensive approach, and care management. The programs often associated case management with patient support and social management, and proposed on-site basic needs. The positive outcomes of these programs concerned mostly the satisfaction obtained by the homeless people through the health care system and the experience that the staff and the students gained. Other frequent positive outcomes were: the change of the social status, the housing status and the access and use of the health care services. The accessibility of services, a limited capacity to enhance continuity of care, the expressed difficulties for the staff to develop multidisciplinary collaboration, and the use of electronic health records were the main limits identified on the programs. The high-performing primary care programs were significantly more likely to track housing status, to include a clinic nurse in staff, to offer on-site social services and basic needs, and to be engaged in the community. Tailored primary care organizations for homeless people led to significant better experience of care for homeless people with or without mental illness, compared to mainstream clinics. Clinic orientation (associated or not with personal health assessment and brief intervention) significantly improved access to health care for homeless people.

\subsection{Integrating Care and Non-Medical Services to Face the Complex Needs of Homeless People}

In this literature review, each primary health care program combined medical, paramedical and non-medical components in various combinations. The medical components were dominated by multidisciplinary approaches, including team-based approaches, integration of health care, coordination, and active collaboration among providers. In the 2000s, coordinated treatment programs for the management of mental illness and substance abuse disorder showed better health outcomes than usual care alone [25]. Fazel et al. recommended that health services focus on the identification and management of somatic diseases (especially infectious diseases and diseases of old age, considering the ageing of homeless people in the USA), and mental illnesses. They also recommended integration "across medical specialties, particularly with treatment providers for addictions, and also to address unmet social and housing needs" [1]. In a qualitative study led in Marseille regarding general practitioners, maintaining a stable follow-up was a major condition for GPs to contribute effectively to the care of homeless people This study identified some key answers to improve the continuity of the health care for homeless people: active outreach, individual support, multidisciplinary and team-based approach, and enhanced social management involving closer relations between medical actors and social workers [53]. These elements lead us to conclude that primary health care programs which develop multidisciplinary care as teams, integration of health care between somatic and mental health, and integration between health and social services are more suitable to address homeless patients' complex needs.

\subsection{Resolving the Debate between Tailored and Non-Tailored Programs to Take Care of Homeless People?}

Wright et al. described three main frameworks that provide primary health care to homeless people [54]: the first is mainstream general practice (most of the time with a "special interest" on homeless people), the second is a "specialized" general practice that registers only homeless people (tailored programs for homeless people), and the third is primary health care provided for homeless people in hospital secondary care. 
As found in this study, the recent literature has shown that tailored programs were more effective, provided more appropriate care and a better experience of care than the standard primary health care $[24,44,55]$, yet many limitations of tailored programs were described in the literature. Firstly, these programs sometimes have insufficient resources to meet such high-level care requirements [56]: this limit concerns mostly non-governmental associations involving volunteer workers. Secondly, for some authors, it can cause a feeling of humiliation, and engender a decreased seeking of care by their patients [57]. Lastly, Lester et al. explained that parallel pathways could reinforce the feeling of exclusion of the homeless, and enhance the ghettoization of their care [58]. Those authors proposed a better model that might combine specialized and mainstream primary care services. In such a model, they recommended that homeless people could register with a specialized homeless practice when they are in crisis. Once their urgent needs have been met, homeless people could then be helped to permanently register within mainstream general practice. This model creates a bridge between separation and integration of tailored and non-tailored services for the homeless. Only 2 programs in this study involved non-tailored primary care collaborations with tailored structures. Even if the results seemed positive, in one study the lack of a primary care registration was highlighted as a limit. The lack of information about non-tailored structures collaborating with tailored structures makes us unable to say for sure that a model with a close collaboration between non-tailored primary care centres and the tailored structures can be a fair transitional solution.

\subsection{Other Efficient Interventions Should Be Associated to Primary Care Programs for Homeless People}

The literature reviews offered some evidence suggesting that the orientation to clinic services available either alone or combined with the outreach improves the access to primary care providers among adults who are homeless, without serious mental illness, and living in urban centres [12]. Other interventions which do not concern primary care seem to improve access to health care, health status, or housing status for homeless people. An international program that has the main activity of housing the homeless people and associate case management and social support ("Housing first") improved outcomes for homeless people with serious mental illness [24]. Case management and assertive case management were also identified as being effective in improving psychiatric symptoms, and decreasing substance use for homeless people with substance abuse issues [25]. Improving the global health of homeless people cannot depend only on primary care programs. It should associate other interventions, acting on housing, social support or specific health needs (mental health, substance abuse, for example).

\subsection{Strenghts and Limitations of This Study}

This literature review gives a comprehensive and a deep understanding of the primary care programs developed for homeless people. The other recent literature reviews targeted only the programs evaluated in high-quality quantitative and comparative studies. In these reviews, if the included articles and the review's method were of high quality, the main and only setback was the low number of articles that could be included [12,24-26]. We then decided to include high- to low-quality studies, and all the types of study (from clinical trial to qualitative studies). As a result of this choice, the internal validity of our results was limited. Indeed, only 3 studies (1 comparative survey and 2 randomized trials) were classified with good internal validity. That is why this literature review gives little evidence over the efficiency of the primary care programs that were designed for homeless people.

We detailed in this review the main components of the primary health care's interventions and organizations. Nevertheless, the efficiency of the primary care programs for homeless people may also depend on the different systems of health care [59]. It would be interesting to explore how these programs work and what is their impact considering the various global health care systems of each country.

The programs described in this review often involved multidisciplinary partnerships or participative approaches to community care. The studies included also described participatory research 
actions, which is the co-construction of research through partnerships between researchers and people affected by and/or responsible for action on the issues under study [60,61]. We did not use terms relative to community-based and/or participative approaches in this review. It would be interesting to explore the field of research for homeless people.

\section{Conclusions}

The primary care programs included in this literature review used mostly team-based approaches, multidisciplinary and/or integrated care. They often proposed co-located services between somatic, mental health and social support, and they tried to answer the specific needs of homeless people. This review isolated some characteristics that have proven effective: tailored primary care organizations for homeless people, clinic orientation (that improved the access to the health care system for homeless people), multidisciplinary team-based models, including primary care physicians and clinic nurses, integration of social support (housing support, co-located social services, and on-site basic needs availability), and engagement in community health. The majority of the studies described tailored primary care programs; therefore, it is necessary to evaluate more non-tailored primary care programs that collaborate with tailored structures in order to be able to take into discussion the efficiency of such programs.

Supplementary Materials: The following are available online at www.mdpi.com/1660-4601/15/2/309/s1, Table S1. Description of programs in primary care caring for homeless people.

Acknowledgments: The authors thank the Club Marseille Doyen and THERY Didier, president of the "commission du leg Maurice OPOCZYNSKI", for providing to the first author a prize during year 2015, which helped to have more time to work on this review. The authors also thank Mister Octavian Stefan who contributed to the language editing of this article.

Author Contributions: Maeva Jego and Stéphanie Gentile conceived and designed the method of this review; Maeva Jego and Julien Abcaya selected the articles, analyzed the articles included in this review, and classified the data; Maeva Jego and Julien Abcaya wrote the paper; Stéphanie Gentile contributed to enhancing the analysis and reviewing the paper; Diana-Elena Ștefan contributed to writing and reviewing the paper and language editing; Céline Calvet-Montredon contributed to writing and reviewing the paper.

Conflicts of Interest: The authors declare no conflict of interest. The founding sponsors had no role in the design of the study; in the collection, analyses, or interpretation of data; in the writing of the manuscript, and in the decision to publish the results.

\section{References}

1. Fazel, S.; Geddes, J.R.; Kushel, M. The health of homeless people in high-income countries: Descriptive epidemiology, health consequences, and clinical and policy recommendations. Lancet 2014, 384, 1529-1540. [CrossRef]

2. FEANTSA. ETHOS-European Typology of Homelessness and Housing Exclusion [Internet]. 2006. Available online: http:/ / www.feantsa.org/en/toolkit/2005/04/01/ethos-typology-on-homelessness-and-housingexclusion (accessed on 8 December 2017).

3. Fondation Abbé Pierre. 22e Rapport sur l'état du Mal-Logement en France en 2017; Fondation Abbé Pierre: Paris, France, 2017; p. 430. (In French)

4. FNARS (Fédération Nationale des Associations D'accueil et de Réinsertion Sociale). Rapport Annuel du 115, Année 2014 [Internet]. 2014. France. Available online: http:/ /www.federationsolidarite.org/images/stories / barometres/Rapport_annuel_115_-_ann\{e\}e_2014.pdf (accessed on 9 December 2017). (In French)

5. Kerker, B.D.; Bainbridge, J.; Kennedy, J.; Bennani, Y.; Agerton, T.; Marder, D.; Forgione, L.; Faciano, A.; Thorpe, L.E. A population-based assessment of the health of homeless families in New York City, 2001-2003. Am. J. Public Health 2011, 101, 546-553. [CrossRef] [PubMed]

6. Baggett, T.P.; Hwang, S.W.; O'Connell, J.J.; Porneala, B.C.; Stringfellow, E.J.; Orav, E.J.; Singer, D.E.; Riqotti, N.A. Mortality among homeless adults in Boston: Shifts in causes of death over a 15-year Period. JAMA Intern. Med. 2013, 173, 189-195. [CrossRef] [PubMed] 
7. Lebrun-Harris, L.A.; Baggett, T.P.; Jenkins, D.M.; Sripipatana, A.; Sharma, R.; Hayashi, A.S.; Daly, C.A.; Ngo-Metzger, Q. Health status and health care experiences among homeless patients in federally supported health centers: Findings from the 2009 patient survey. Health Serv. Res. 2013, 48, 992-1017. [CrossRef] [PubMed]

8. Schanzer, B.; Dominguez, B.; Shrout, P.E.; Caton, C.L.M. Homelessness, Health Status, and Health Care Use. Am. J. Public Health 2007, 97, 464-469. [CrossRef] [PubMed]

9. Nielsen, S.F.; Hjorthøj, C.R.; Erlangsen, A.; Nordentoft, M. Psychiatric disorders and mortality among people in homeless shelters in Denmark: A nationwide register-based cohort study. Lancet 2011, 377, 2205-2214. [CrossRef]

10. Strehlau, V.; Torchalla, I.; Kathy, L.; Schuetz, C.; Krausz, M. Mental health, concurrent disorders, and health care utilization in homeless women. J. Psychiatr. Pract. 2012, 18, 349-360. [CrossRef] [PubMed]

11. Laporte, A.; Chauvin, P. Samenta: Rapport sur la Santé Mentale et les Addictions Chez les Personnes sans Logement Personnel D’Ile-de-France. Observatoire du Samu Social. 2004, p. 227. Available online: http:/ / www.hal.inserm.fr/inserm-00471925 (accessed on 10 February 2018). (In French)

12. Health Quality Ontario. Interventions to Improve Access to Primary Care for People Who Are Homeless: A Systematic Review. Ont. Health Technol. Assess. Ser. 2016, 16, 1-50.

13. McGuire, J.; Gelberg, L.; Blue-Howells, J.; Rosenheck, R.A. Access to primary care for homeless veterans with serious mental illness or substance abuse: A follow-up evaluation of co-located primary care and homeless social services. Adm. Policy Ment. Health Ment. Health Serv. Res. 2009, 36, 255-264. [CrossRef] [PubMed]

14. Khandor, E.; Mason, K.; Chambers, C.; Rossiter, K.; Cowan, L.; Hwang, S.W. Access to primary health care among homeless adults in Toronto, Canada: Results from the Street Health survey. Open Med. 2011, 5, e94. [PubMed]

15. Kushel, M. The First Step is the Hardest: Overcoming Barriers to Primary Care. J. Gen. Intern. Med. 2015, 30, 868-869. [CrossRef] [PubMed]

16. Cowan, L.; Hwang, S.; Khandor, E.; Mason, K. The Street Health Report 2007; Street Health: Toronto, ON, Canada, 2007.

17. Farnarier, C.; Fano, M.; Magnani, C.; Jaffré, Y. Rapport de recherche. Projet TREPSAM (Trajectoire de soins des Personnes Sans-Abri à Marseille), rapport final. Unité mixte internationale Nº3189—Environnement, santé, sociétés. 2015. Available online: http:/ /lassa-org.fr/wp-content/uploads/2012/04/TREPSAM-RapportSyntheseFinal.pdf (accessed on 9 February 2018).

18. Hwang, S.W.; Chambers, C.; Chiu, S.; Katic, M.; Kiss, A.; Redelmeier, D.A.; Levinson, W. A comprehensive assessment of health care utilization among homeless adults under a system of universal health insurance. Am. J. Public Health 2013, 103, S294-S301. [CrossRef] [PubMed]

19. Bharel, M.; Lin, W.-C.; Zhang, J.; O'Connell, E.; Taube, R.; Clark, R.E. Health care utilization patterns of homeless individuals in Boston: Preparing for Medicaid expansion under the Affordable Care Act. Am. J. Public Health 2013, 103, S311-S317. [CrossRef] [PubMed]

20. Tsai, J.; Doran, K.M.; Rosenheck, R.A. When health insurance is not a factor: National comparison of homeless and nonhomeless U.S. veterans who use Veterans Affairs Emergency Departments. Am. J. Public Health 2013, 103, S225-S231. [CrossRef] [PubMed]

21. Hwang, S.W.; Ueng, J.J.M.; Chiu, S.; Kiss, A.; Tolomiczenko, G.; Cowan, L.; Levinson, W.; Redelmeier, D.A. Universal Health Insurance and Health Care Access for Homeless Persons. Am. J. Public Health 2010, 100, 1454-1461. [CrossRef] [PubMed]

22. World Health Organization \& Unicef. Report of the International Conference on Primary Health Care; World Health Organization: Geneva, Switzerland, 1978; p. 38.

23. Joyce, D.P.; Limbos, M. Identification of cognitive impairment and mental illness in elderly homeless men: Before and after access to primary health care. Can. Fam. Physician 2009, 55, 1110-1111. [PubMed]

24. O'Toole, T.P.; Buckel, L.; Bourgault, C.; Blumen, J.; Redihan, S.G.; Jiang, L.; Friedmann, P. Applying the chronic care model to homeless veterans: Effect of a population approach to primary care on utilization and clinical outcomes. Am. J. Public Health 2010, 100, 2493-2499. [CrossRef] [PubMed]

25. Hwang, S.W.; Burns, T. Health interventions for people who are homeless. Lancet 2014, 384, $1541-1547$. [CrossRef] 
26. Hwang, S.W.; Tolomiczenko, G.; Kouyoumdjian, F.G.; Garner, R.E. Interventions to Improve the Health of the Homeless: A Systematic Review. Centre for Reviews and Dissemination (UK), 2005. Available online: https:/ / www.ncbi.nlm.nih.gov/books/NBK71506/ (accessed on 8 November 2017).

27. Fitzpatrick-Lewis, D.; Ganann, R.; Krishnaratne, S.; Ciliska, D.; Kouyoumdjian, F.; Hwang, S.W. Effectiveness of interventions to improve the health and housing status of homeless people: A rapid systematic review. BMC Public Health 2011, 11, 638. [CrossRef] [PubMed]

28. de Vet, R.; van Luijtelaar, M.J.A.; Brilleslijper-Kater, S.N.; Vanderplasschen, W.; Beijersbergen, M.D.; Wolf, J.R.L.M. Effectiveness of case management for homeless persons: A systematic review. Am. J. Public Health 2013, 103, e13-e26. [CrossRef] [PubMed]

29. Vanderplasschen, W.; Wolf, J.; Rapp, R.C.; Broekaert, E. Effectiveness of Different Models of Case Management for Substance-Abusing Populations. J. Psychoact. Drugs 2007, 39, 81-95. [CrossRef] [PubMed]

30. Perez-Merino, R. Strategies for enhancing the delivery of person-centred care. Nurs. Stand. 2014, $28,37-41$. [CrossRef] [PubMed]

31. Atkins, D.; Eccles, M.; Flottorp, S.; Guyatt, G.H.; Henry, D.; Hill, S.; Liberati, A.; O'Connell, D.; Oxman, A.D.; Phillips, B.; et al. Systems for grading the quality of evidence and the strength of recommendations I: Critical appraisal of existing approaches The GRADE Working Group. BMC Health Serv. Res. 2004, 4, 38. [CrossRef] [PubMed]

32. Harris, R.P.; Helfand, M.; Woolf, S.H.; Lohr, K.N.; Mulrow, C.D.; Teutsch, S.M.; Atkins, D. Current methods of the US Preventive Services Task Force: A review of the process. Am. J. Prev. Med. 2001, 20, 21-35. [CrossRef]

33. Agency for Healthcare Research and Quality. U.S. Preventive Services Task Force Procedure Manual; Agency for Healthcare Research and Quality: Rockville, MD, USA, 2008.

34. Rowan, M.S.; Mason, M.; Robitaille, A.; Labrecque, L.; Tocchi, C.L. An innovative medical and dental hygiene clinic for street youth: Results of a process evaluation. Eval. Progr. Plann. 2013, 40, 10-16. [CrossRef] [PubMed]

35. O'Toole, T.P. Tailoring Care to Vulnerable Populations by Incorporating Social Determinants of Health: The Veterans Health Administration's “Homeless Patient Aligned Care Team” Program. Prev. Chronic Dis. 2016, 13. Available online: https:/ /www.cdc.gov/pcd/issues/2016/15_0567.htm (accessed on 27 September 2017).

36. O'Toole, T.P.; Johnson, E.E.; Borgia, M.L.; Rose, J. Tailoring Outreach Efforts to Increase Primary Care Use Among Homeless Veterans: Results of a Randomized Controlled Trial. J. Gen. Intern. Med. 2015, 30, 886-898. [CrossRef] [PubMed]

37. Patel, B.I. Complex Care Management to Decrease Emergency Department Utilization: A Case Study of the Homeless Patient Aligned Care Team Demonstration Project at VA Greater Los Angeles Healthcare-Escholarship. UCLA, 2013. Available online: https://escholarship.org/uc/item/1681c184 (accessed on 28 November 2017).

38. O'Toole, T.P.; Bourgault, C.; Johnson, E.E.; Redihan, S.G.; Borgia, M.; Aiello, R.; Kane, V. New to care: Demands on a health system when homeless veterans are enrolled in a medical home model. Am. J. Public Health 2013, 103, S374-S379. [CrossRef] [PubMed]

39. Simons, D.; Pearson, N.; Movasaghi, Z. Developing dental services for homeless people in East London. Br. Dent. J. 2012, 213, E11. [CrossRef] [PubMed]

40. Uddin, J.; Koehlmoos, T.P.; Saha, N.C.; Islam, Z.; Khan, I.A.; Quaiyum, M. Strategies for providing healthcare services to street-dwellers in Dhaka city: Evidence from an operations research. Health Res. Policy Syst. 2012, 10, 19. [CrossRef] [PubMed]

41. Stergiopoulos, V.; Schuler, A.; Nisenbaum, R.; deRuiter, W.; Guimond, T.; Wasylenki, D.; Hoch, J.S.; Hwang, S.W.; Rouleau, K.; Dewa, C. The effectiveness of an integrated collaborative care model vs. a shifted outpatient collaborative care model on community functioning, residential stability, and health service use among homeless adults with mental illness: A quasi-experimental study. BMC Health Serv. Res. 2015, 15, 348. [CrossRef] [PubMed]

42. Campbell, D.J.; Gibson, K.; O’Neill, B.G.; Thurston, W.E. The role of a student-run clinic in providing primary care for Calgary's homeless populations: A qualitative study. BMC Health Serv. Res. 2013, 13, 277. [CrossRef] [PubMed]

43. Omori, J.S.; Riklon, S.; Wong, V.S.; Lee, D.F. The Hawai'i Homeless Outreach and Medical Education Project: Servicing the community and our medical students. Hawaii J. Med. Public Health 2012, 71, 262-265. [PubMed] 
44. Kertesz, S.G.; Holt, C.L.; Steward, J.L.; Jones, R.N.; Roth, D.L.; Stringfellow, E.; Gordon, A.J.; Kim, T.W.; Austin, E.L.; Henry, S.R.; et al. Comparing Homeless Persons' Care Experiences in Tailored Versus Nontailored Primary Care Programs. Am. J. Public Health 2013, 103, S331-S339. [CrossRef] [PubMed]

45. Chrystal, J.G.; Glover, D.L.; Young, A.S.; Whelan, F.; Austin, E.L.; Johnson, N.K.; Pollio, D.E.; Holt, C.L.; Stringfellow, E.; Gordon, A.J.; et al. Experience of primary care among homeless individuals with mental health conditions. PLoS ONE 2015, 10, e0117395. [CrossRef] [PubMed]

46. Weinstein, L.C.; LaNoue, M.; Collins, E.; Henwood, B.F.; Drake, R.E. Health Care Integration for Formerly Homeless People with Serious Mental Illness. J. Dual Diagn. 2013, 9, 72-77. [CrossRef]

47. Weinstein, L.C.; Lanoue, M.D.; Plumb, J.D.; King, H.; Stein, B.; Tsemberis, S. A primary care-public health partnership addressing homelessness, serious mental illness, and health disparities. J. Am. Board Fam. Med. 2013, 26, 279-287. [CrossRef] [PubMed]

48. Upshur, C.; Weinreb, L.; Bharel, M.; Reed, G.; Frisard, C. A randomized control trial of a chronic care intervention for homeless women with alcohol use problems. J. Subst. Abus. Treat. 2015, 51, 19-29. [CrossRef] [PubMed]

49. Hewett, N.; Buchman, P.; Musariri, J.; Sargeant, C.; Johnson, P.; Abeysekera, K.; Grant, L.; Oliver, E.A.; Eleftheriades, C.; McCormick, B.; et al. Randomised controlled trial of GP-led in-hospital management of homeless people ('Pathway'). Clin. Med. 2016, 16, 223-229. [CrossRef] [PubMed]

50. Lamb, V.; Joels, C. Improving access to health care for homeless people. Nurs. Stand. 2014, $29,45-51$. [CrossRef] [PubMed]

51. Dang, M.T.; Whitney, K.D.; Virata, M.C.D.; Binger, M.M.; Miller, E. A web-based personal health information system for homeless youth and young adults. Public Health Nurs. 2012, 29, 313-319. [CrossRef] [PubMed]

52. Held, M.L.; Brown, C.A.; Frost, L.E.; Hickey, J.S.; Buck, D.S. Integrated Primary and Behavioral Health Care in Patient-Centered Medical Homes for Jail Releasees with Mental Illness. Crim. Justice Behav. 2012, 39, 533-551. [CrossRef]

53. Jego, M.; Grassineau, D.; Balique, H.; Loundou, A.; Sambuc, R.; Daguzan, A.; Gentile, G.; Gentile, S. Improving access and continuity of care for homeless people: How could general practitioners effectively contribute? Results from a mixed study. BMJ Open 2016, 6, e013610. [CrossRef] [PubMed]

54. Wright, N.M.; Tompkins, C.N. How can health services effectively meet the health needs of homeless people? Br. J. Gen. Pract. 2006, 56, 286-293. [PubMed]

55. Hanlon, P.; Yeoman, L.; Esiovwa, R.; Gibson, L.; Williamson, A.E.; Mair, F.S.; Lowrie, R. Interventions by healthcare professionals to improve management of physical long-term conditions in adults who are homeless: A systematic review protocol. BMJ Open 2017, 7, e016756. [CrossRef] [PubMed]

56. Crane, M.; Warnes, A.M. Primary health care services for single homeless people: Defects and opportunities. Fam. Pract. 2001, 18, 272-276. [CrossRef] [PubMed]

57. Parizot, I.; Chauvin, P. The access to care of underserved populations: A research among free clinics patients in the Paris area. Rev. Epidemiol. Sante Publique 2003, 51, 577-588. [PubMed]

58. Lester, H.; Wright, N.; Heath, I. Developments in the provision of primary health care for homeless people. Br. J. Gen. Pract. 2002, 52, 91-92. [PubMed]

59. Verlinde, E.; Verdée, T.; Van de Walle, M.; Art, B.; De Maeseneer, J.; Willems, S. Unique health care utilization patterns in a homeless population in Ghent. BMC Health Serv. Res. 2010, 10, 242. [CrossRef] [PubMed]

60. Jagosh, J.; Bush, P.L.; Salsberg, J.; Macaulay, A.C.; Greenhalgh, T.; Wong, G.; Cargo, M.; Green, L.W.; Herbert, C.P.; Pluye, P. A realist evaluation of community-based participatory research: Partnership synergy, trust building and related ripple effects. BMC Public Health 2015, 15, 725. [CrossRef] [PubMed]

61. Jagosh, J.; Macaulay, A.C.; Pluye, P.; Salsberg, J.; Bush, P.L.; Henderson, J.; Sirett, E.; Wong, G.; Cargo, M.; Herbert, C.P.; et al. Uncovering the benefits of participatory research: Implications of a realist review for health research and practice. Milbank Q. 2012, 90, 311-346. [CrossRef] [PubMed]

(C) 2018 by the authors. Licensee MDPI, Basel, Switzerland. This article is an open access article distributed under the terms and conditions of the Creative Commons Attribution (CC BY) license (http:/ / creativecommons.org/licenses/by/4.0/). 